Zagorski, M. E. and R. K. Swihart. 2021. Raptor resource use in agroecosystems: cover crops and definitions of availability matter. Avian Conservation and Ecology 16(1):1. https://doi.org/10.5751/ACE-01719-160101

Copyright (C) 2021 by the author(s). Published here under license by the Resilience Alliance.

Research Paper

\title{
Raptor resource use in agroecosystems: cover crops and definitions of availability matter
}

\author{
Megan E. Zagorski ${ }^{1}$ and Robert K. Swihart ${ }^{1}$ \\ ${ }^{1}$ Department of Forestry and Natural Resources, Purdue University
}

\begin{abstract}
The populations of many species of raptors that forage in agroecosystems have declined as agriculture has intensified. Cover crops are a recent trend in areas of intensive row-crop agriculture in the Midwestern United States that could positively affect raptors by increasing the abundance and distribution of raptor prey. We assessed the habitat use of two raptors, American Kestrel (Falco sparverius) and Red-tailed Hawk (Buteo jamaicensis), and tested for use of areas near cover-cropped fields. We conducted 1184 $\mathrm{km}$ of roadside transects in 2018 and 2019 in west-central Indiana and recorded 191 detections of our focal species. We constructed resource selection functions within a use-availability design to evaluate raptor habitat use with a series of weighted logistic regression models. For each species, we fitted models at two scales (transect and landscape) and with two definitions of available points (completely random and random subject to perch constraints). American Kestrels were strongly associated with cover-cropped agricultural fields. Red-tailed Hawks were strongly associated with woodlots. Scale did not greatly affect the inclusion of habitat variables into top models for either species. Random models identified potential perch sites, whereas constrained random models identified more subtle habitat preferences not included in the random models. For American Kestrels, constrained models revealed reduced use of woodland perches and increased use of perches near cover-cropped and conventional agricultural fields. For Red-tailed Hawks, constrained models revealed habitat associations, particularly reduced use of utility lines and human development, that were absent or de-emphasized in random models. Modeling resource selection with constrained random availability will work best for well-studied species with discrete, easily mapped habitat features. If damage to commodity crops by rodents in cover-cropped fields is a concern, raptor management should focus on kestrels and could include erection of artificial perches, nest boxes, and enhancement of permanent herbaceous habitats for hunting.
\end{abstract}

\section{Utilisation des ressources par les rapaces dans les agroécosystèmes : les cultures de couverture et la définition de la disponibilité importent}

RÉSUMÉ. Les populations de nombreuses espèces de rapaces qui se nourrissent dans les agroécosystèmes ont diminué avec l'intensification de l'agriculture. Les cultures de couverture, une tendance récente dans les zones de cultures intensives en rangs du Midwest des États-Unis, pourraient avoir un effet positif sur les rapaces en permettant d'augmenter l'abondance et la répartition de leurs proies. Nous avons évalué l'utilisation d'habitat de deux rapaces, la Crécerelle d'Amérique (Falco sparverius) et la Buse à queue rousse (Buteo jamaicensis), et testé l'utilisation des zones près des champs de cultures de couverture. Nous avons inventorié $1184 \mathrm{~km}$ de transects en bord de routes en 2018 et 2019 dans le centre-ouest de l'Indiana et noté 191 détections de nos espèces cibles. Nous avons construit des fonctions de sélection des ressources dans le cadre d'un plan utilisation-disponibilité pour évaluer l'utilisation d'habitat par les rapaces à l'aide d'une série de modèles de régression logistique pondérée. Pour chaque espèce, nous avons ajusté les modèles à deux échelles (transect et paysage) et selon deux définitions de disponibilité (complètement aléatoire ou aléatoire avec contraintes de perchoir). Les crécerelles ont été fortement associées aux champs de cultures de couverture. Les buses étaient fortement associées aux boisés. L'échelle n'a pas eu un grand effet sur l'inclusion des variables d'habitat dans les meilleurs modèles pour les deux espèces. Les modèles aléatoires ont identifié des sites potentiels pour se percher, tandis que les modèles aléatoires avec contraintes ont identifié des préférences d'habitat plus subtiles et non incluses dans les modèles aléatoires. Pour les crécerelles, les modèles avec contraintes ont révélé une utilisation réduite des perchoirs en forêt et une utilisation accrue des perchoirs à proximité des champs de cultures de couverture et de cultures conventionnelles. Pour les buses, les modèles avec contraintes ont révélé des associations avec l'habitat, en particulier une faible utilisation des lignes de services publics et des aménagements humains, quiétaient absentes ou atténuées dans les modèles aléatoires. La modélisation de la sélection des ressources avec une disponibilité aléatoire contrainte fonctionnera mieux pour les espèces bien étudiées ayant des caractéristiques d'habitat distinctes et faciles à cartographier. Si les dommages causés aux cultures principales par les rongeurs dans les cultures de couverture sont un problème, la gestion des rapaces devrait se concentrer sur les crécerelles et pourrait comprendre l'installation de perchoirs artificiels et de nichoirs et l'amélioration des milieux herbacés permanents pour la chasse.

Key Words: American Kestrel; Buteo jamaicensis; cover crops; Falco sparverius; Red-tailed Hawk; resource selection function; row-crop agroecosystems; use-availability

Address of Correspondent: Megan E Zagorski, Department of Forestry and Natural Resources,, Purdue University,, West Lafayette, IN, USA, , , , zagorski.megan@gmail.com 


\section{INTRODUCTION}

In the midwestern United States, conversion of grassland and forest, primarily due to agriculture, has dramatically reduced and fragmented permanent habitat for wildlife (Kremen et al. 2002, Stanton et al. 2018). For instance, across Indiana, tallgrass prairie and forest currently cover $<1 \%$ and $<25 \%$, respectively, of their extent before European settlement (Samson and Knopf 1994, Carman 2013). Intensive row-crop agriculture has dominated the region for $>50$ years and is characterized by high levels of chemical inputs and monocrop annual rotations of $2-3$ crops, usually corn (Zea mays), soybeans (Glycine max), or wheat (Triticum aestivum), planted in large fields (Griffith et al. 1977, Yan and Roy 2016). Since 1985, the federal Conservation Reserve Program (CRP) has attempted to mitigate habitat losses in agroecosystems by taking enrolled land out of production to be managed as restored permanent cover, typically grassland in the Midwest, over the course of a contract (Morefield et al. 2016).

In agroecosystems, raptor distributions are influenced by the availability of perches and prey abundance, with raptor abundances typically declining as agriculture becomes more intensive (Boano and Toffoli 2002, Filloy and Bellocq 2007, Butet et al. 2010, Grande et al. 2018 and sources therein). Although artificial nest boxes and perches can improve raptor habitat quality in agricultural landscapes (Fargallo et al. 2009, Paz et al. 2012, Shave and Lindell 2017), artificial perches are not commonly available and there is no organized network of nest boxes in our study area (Zagorski and Swihart 2020). Other initiatives, such as CRP and related programs (e.g., Agricultural Conservation Easement Program (ACEP) and the Environmental Quality Incentives Program (EQIP)), have benefited raptors and other wildlife (Best et al. 1997a, 1997b, Riffell et al. 2008, Rollins and Lyons 2009, Wilson et al. 2010, Ehrenberger and Dunning 2011, Mushet et al. 2014, Otto et al. 2018, Lewis et al. 2019). Unfortunately, CRP enrollment, both nationally and in the Midwest, has dropped in recent years, and conversion to cropland has increased (Morefield et al. 2016).

Cover crops may offset negative effects experienced by wildlife due to declining CRP enrollment, especially in winter. These crops are non-commodity crops usually planted after the fall harvest to improve soil drainage and reduce soil compaction, erosion, nutrient loss, and weed growth (Dabney et al. 2001, Villamil et al. 2006). An additional benefit of cover crops is the vegetative habitat they can provide to wildlife through the winter and early spring, with increased abundances documented for native bees and birds (Ellis and Barbercheck 2015, Wilcoxen et al. 2018). Use of cover crops has grown rapidly in the past decade, and Indiana ranks $3^{\text {rd }}$ in the United States in terms of cover crop adoption with $>375,000$ ha of cover crops planted annually since 2014 (Indiana State Department of Agriculture 2019, USDA NASS 2019a).

Cover crops also likely provide an adequate habitat for voles (Microtus) and other small mammals that are important prey for raptors (Jug et al. 2008, Fisher et al. 2014). Voles in particular are agricultural pests that can damage or consume cash crops, and producers have reported damage to cover-cropped soybean fields in Indiana (Fisher et al. 2014, Prieur and Swihart 2020a). The principal prey of many raptors, voles prefer dense herbaceous habitats, such as wheat and alfalfa (Medicago sativa) fields
(Craighead and Craighead 1956, Babińska-Werka 1979, Baker and Brooks 1981, Getz and Brighty 1986, Kaufman and Kaufman 1990). Common cover crops such as cereal rye (Secale cereale) provide a similar vegetative profile that likely promotes a greater abundance of voles relative to conventional fields (Conservation Technology Information Center 2017). Hence, cover-cropped fields may contain higher densities of small mammal prey.

We investigated use of winter hunting habitat (Jones 2001) by two raptors in west-central Indiana that hunt in open areas of midwestern agroecosystems: American Kestrels (Falco sparverius) and Red-tailed Hawks (Buteo jamaicensis). Although Red-tailed Hawks are one of the most common hawks in North America, American Kestrels have undergone steep declines throughout much of their range in the past 40 years (Farmer and Smith 2009, Smallwood 2009). Our primary objective was to test whether these raptors preferentially use areas in proximity to cover-cropped fields. Raptors typically forage where prey densities are highest (Baker and Brooks 1981, Preston and Beane 1996, Worm et al. 2013). Thus, if raptor responses are driven by prey density, raptor use should be greater in areas proximal to cover-cropped fields and other areas of high-quality habitat for prey. Alternatively, if dense vegetation discourages raptor habitat use (Craighead and Craighead 1956, Bechard 1982, Preston 1990), an increased presence at more exposed sites with greater ease of prey capture is predicted.

The two focal species are sit-and-wait predators, hunting primarily from perches (Bildstein 1978, Preston and Beane 2009), although American Kestrels also hunt by hovering (Collopy and Koplin 1983, Bildstein and Collopy 1987). Thus, a secondary objective was to evaluate whether explicitly incorporating into analyses constraints of perch availability affected conclusions regarding factors that influence site use.

\section{METHODS}

\section{Study area}

We surveyed agricultural landscapes with roadside transects in a 10-county area of central Indiana (Fig. 1). These counties are characterized by intensive row-crop agriculture with $60-90 \%$ of land planted to either corn or soybeans (USDA NASS 2019b). Cover crop adoption ranged from $2-28 \%$ in the surveyed counties (Indiana State Department of Agriculture 2019). We did not identify cover crops to species, but the five most commonly planted winter-hardy cover crops in the area were cereal rye, rapeseed (Brassica napus), winter wheat, annual ryegrass (Lolium multiflorum), and crimson clover (Trifolium incarnatum, Conservation Technology Information Center 2017).

\section{Data collection}

\section{Transects}

We designed our transects in Google Earth Pro 2018 (Google, Mountain View, California, USA), and attempted to maximize the surrounding agricultural landscape while also maintaining routes that were as straight as possible to aid aerial imaging flights. Following these constraints, transects were randomly placed on the landscape within each county. Where possible, we limited routes to secondary roads. In 2019 , we repeated 13 of our 14 original transects; one transect was partially rerouted to avoid a 
construction zone, and one with low agricultural landcover was dropped. We added two routes each in counties with 11\% (Pulaski) and 29\% (Miami) cover-crop adoption in 2017 (Indiana State Department of Agriculture 2019). These additional routes were designed after consulting local NRCS offices and 2018 Sentinel-2 (ESA) and Landsat-8 satellite imagery. Transects were driven once per season and averaged $38 \mathrm{~km}$ (range: $29-47 \mathrm{~km}$ ).

Fig. 1. Transect routes surveyed for raptors in west-central Indiana January-April 2018 and 2019.

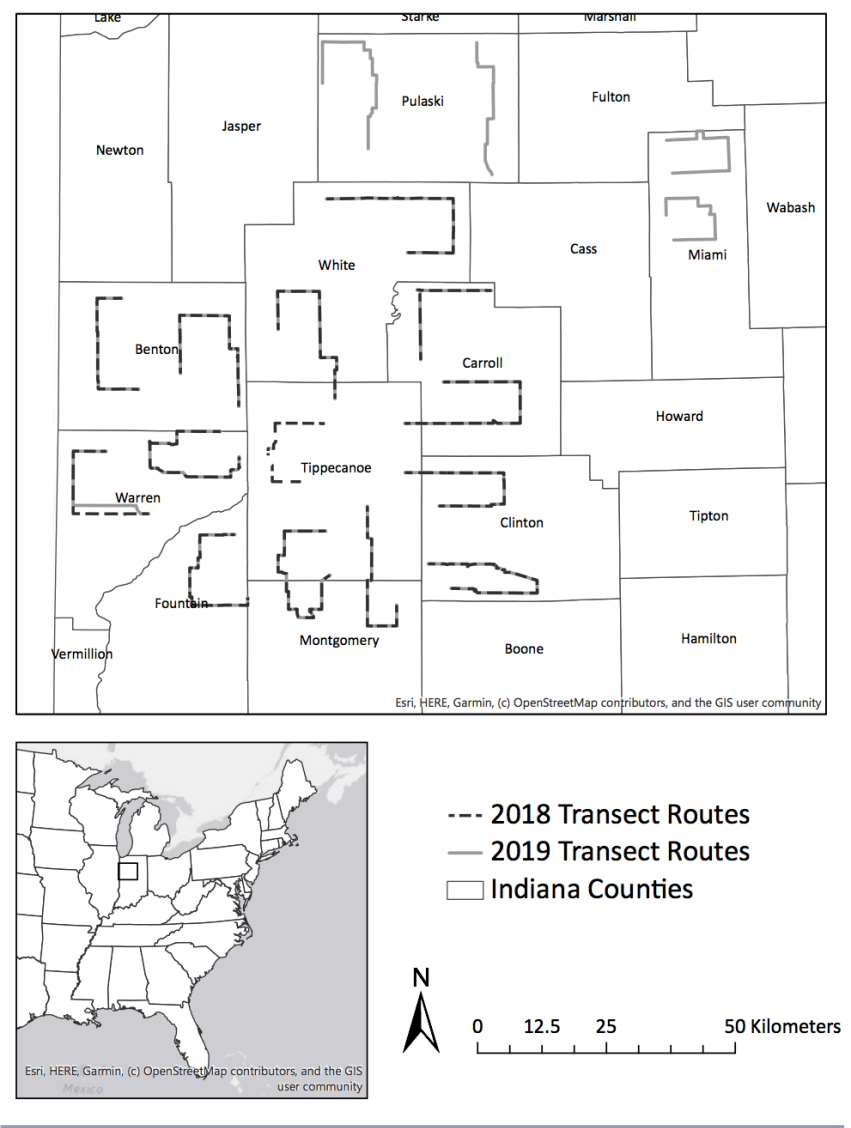

We conducted surveys by driving transects from January 14-April 8, 2018 and January 21-April 2, 2019. To limit temporal bias, in 2019 we surveyed our repeated 2018 routes at similar dates and supplemented the four additional transects throughout the season. We surveyed for raptors beginning 1 hour after sunrise until routes were completed (mean: 2 h $15 \mathrm{~min}$ ) on days where wind was at or below level $4(\leq 29 \mathrm{~km} / \mathrm{h})$ on the Beaufort Scale and precipitation was no heavier than a light flurry or drizzle (Fuller and Mosher 1981, 1987). Other studies have ranged widely in the timing of their transects, but we elected to conduct morning surveys because we were interested in modeling habitat use at times when birds were more likely to be perched rather than soaring (Fuller and Mosher 1981, Bunn et al. 1995). Each transect was surveyed once within a year. To avoid bias due to seasonal changes, we surveyed a single transect in each county, rotated through all counties in the study area, then returned to each county in the same rotation and surveyed a second transect. The only exception was Fountain County, which had only 1 transect and was surveyed in the middle of the sampling season. We drove between $16-24 \mathrm{~km} / \mathrm{h}$ and had two observers counting raptors, with the primary observer scanning both sides of the road and the secondary (driving) observer scanning in front of the vehicle and occasionally on the driver's side (Craighead and Craighead 1956, Fuller and Mosher 1981). The primary observer was the same in both years, but the secondary observer differed between years. We counted all raptors seen along the routes, using a pair of $10 \times 42$ Leupold and Stevens binoculars (Beaverton, Oregon, USA) to confirm identifications. When we saw a raptor, we stopped to note the species, behavior, perching substrate, perpendicular distance (Prostaff $7 \mathrm{i}$ rangefinder, Nikon, Tokyo, Japan), and GPS coordinates from the road (GPSmap 78s Garmin, Olathe, Kansas, USA).

\section{Aerial photography}

Due to the ephemeral nature of cover crops, we obtained aerial imagery of cover crops planted along transects. We timed our flights to coincide with maximum cover-crop growth just before termination: April 19-20, 2018 and April 24-28, 2019. Transects were flown in a Cessna 172P Skyhawk at an altitude of $2000 \mathrm{~m}$ with clear skies or few clouds. A 2000-m altitude allowed us to classify landcover within $1 \mathrm{~km}$ on either side of transect routes. In 2019, five transects were flown at $1800 \mathrm{~m}$ due to a low cloud ceiling, but without adverse effects on landcover classification. All images were taken with a FinePix HS50EXR (Fujifilm, Tokyo, Japan) on the landscape setting from the belly of the plane.

\section{GIS analysis}

Using the aerial imagery, we digitized landcover within $1 \mathrm{~km}$ of each transect in ArcGIS Pro (ESRI, Redlands, California, USA). To classify landcover, we compared the aerial imagery to images of known landcover, and ground-truthed any uncertain areas. We assigned landcover to five classes (Table 1): agricultural fields with traditional cover crops, alfalfa, and wheat (Cover), agricultural fields without a cover crop (NoCover), habitats characterized by permanent herbaceous cover, including CRP strips, grass waterways $10 \mathrm{~m}$ wide, and remnant grasslands (PermHab), woodlots (Woods), and developed areas (Dev). For each landcover class, we calculated the percent of total landcover along each transect.

In addition to landcover, we digitized three habitat features that could serve as potential perches for raptors (Table 1), including linear rows of trees (Treeline, e.g., windbreaks and privacy screens of $\leq 3$ rows of trees), the outer canopy of trees in yards and pastures (Treeperim), and utility lines and poles (Utility). We did not include artificial nest boxes or perches as potential perch sites because they occurred rarely and haphazardly, and typically were attached to habitat features already included in the analysis, such as trees, woodlot edges, utility poles, or buildings. We digitized utility lines based on Google Earth imagery; all of the remaining features were digitized from the aerial imagery. For all features, we only digitized those elements that would have been visible to observers from the road and thus available to survey for raptor presence. For example, for the canopy of trees in yards/pastures, we only digitized the portion of the canopy facing the road, and excluded any trees that would have been hidden by houses or woodlots.

For both American Kestrels and Red-tailed Hawks, we measured the perpendicular distance from the transect to any observed individual and used this distance to map observations in 
Table 1. Landcover and habitat classes used in models of raptor resource selection in agroecosystems of west-central Indiana, U.S.A., 2018-2019. For all features listed, explanatory variables were distance $(\mathrm{m})$ from the focal landcover or habitat class. The variables considered for each species are noted (+). Species abbreviations: AMKE $=$ American kestrel (Falco sparverius) and RTHA = red-tailed hawk (Buteo jamaicensis).

\begin{tabular}{|c|c|c|c|c|}
\hline \multirow[t]{2}{*}{ Explanatory Variables } & & \multirow[t]{2}{*}{ Description } & \multicolumn{2}{|c|}{ Raptor Species } \\
\hline & & & AMKE & RTHA \\
\hline \multicolumn{5}{|l|}{ Landcover } \\
\hline Cover crops & Cover & $\begin{array}{l}\text { Agricultural fields planted with cover crops, alfalfa, or winter } \\
\text { wheat }\end{array}$ & + & + \\
\hline Development & Dev & Towns, buildings, large roads, etc. & + & + \\
\hline No cover crops & NoCover & $\begin{array}{l}\text { Agricultural fields without a cover crop, including no-till and } \\
\text { conventional tillage fields. }\end{array}$ & + & + \\
\hline Permanent habitat & PermHab & $\begin{array}{l}\text { Permanent herbaceous cover, including large grass waterways, } \\
\text { CRP strips, remnant grasslands, etc. }\end{array}$ & + & + \\
\hline Woodlots & Woods & Forested lots & + & + \\
\hline Agriculture & Agriculture & All agricultural fields & + & \\
\hline \multicolumn{5}{|l|}{ Habitat } \\
\hline Utility lines & Utility & Telephone lines, utility wires, poles, and crossbeams & + & + \\
\hline Tree perimeter & Treeperim & The outer perimeter of the canopy of independent trees & + & + \\
\hline Treelines & Treeline & Linear rows of trees & + & + \\
\hline
\end{tabular}

ArcGISPro. For each species, we excluded from analysis any observations beyond the perpendicular distance threshold of 75 $\mathrm{m}$ for American Kestrels and $250 \mathrm{~m}$ for Red-tailed Hawks (Boano and Toffoli 2002, Hutto 2016, 2017, Zagorski 2019). We assumed that we detected all individuals of a species within their respective distance thresholds, as these distances are more conservative than in other raptor studies (Marion and Ryder 1975, Bildstein 1978, Andres 1994, Bunn et al. 1995, Viñuela 1997, Ardia and Bildstein 2001, Boano and Toffoli 2002, Butet et al. 2010). We also excluded any individuals that were not perched or hover-hunting. Perched and hovering individuals were assumed to be actively hunting, an assumption we could not make for birds that were flying through or soaring. For paired raptors, we only included the individual that was observed first to avoid introducing spatial dependencies into our analysis of habitat use. After mapping confirmed raptor observations and generating available points, we calculated the distance to each landcover and habitat feature for every point, and used these distances as the variables in logistic regression models (Conner and Plowman 2001, see below).

\section{Statistical analysis}

We adopted a use-availability design (Johnson et al. 2006) to develop models of resource selection by raptors as a function of distance $(\mathrm{m})$ to each of the measured landcover and habitat features (Table 1, Conner et al. 2003). Distance-based analyses are more informative than analyses based on habitat categories because the former can incorporate both linear (potential perches) and areal (landcover) features. In particular, a distance-based analysis allowed us to investigate the relationship between raptor locations and all habitat features, not just the select few, principally NoCover, that fell within a certain radius of each point.

Estimates derived from logistic regression for use-availability data converge to an equivalent log-linear inhomogeneous point process model if the number of available points is sufficiently large or infinite weights are assigned to all available points (Warton and Shepherd 2010, Fithian and Hastie 2013). Following Muff et al.
(2020), we standardized each explanatory variable (Table 1) to have a mean of 0 and standard deviation of 1 , and weighted available points by a factor of 1000 . When detections are infrequent, as in our study, the random selection of a large number of available points can improve model accuracy (Lobo and Tognelli 2011, Nad'o and Kaňuch 2018). Thus, we selected 1000 random points for each model set; this was the sample size at which mean distances from available points to covariates tended to stabilize (Benson 2013, Zagorski 2019).

We fit a series of weighted logistic regression models for each focal species in R 3.6.1 ( $\mathrm{R}$ Core Team 2019). First, we fit a global additive model to compare with our set of candidate models. We checked for multicollinearity by calculating variance inflation factors for all variables in each global model with the car package (Fox and Weisberg 2019). We then compared all possible additive models containing $p$ or fewer explanatory variables using package MuMIn (Shoemaker et al. 2018, Barton 2019). Due to the relatively low number of detections for the species, we guarded against overparameterizing models by fitting a maximum of $p=$ 4 explanatory variables to models for Red-tailed Hawks ( $n=72$ detections) and American Kestrels $(n=43)$. For each model set, we quantified the prevalence of each covariate in the credible set of models relative to its prevalence in the entire set of models. A credible set was defined as the top models with a collective Akaike weight $\geq 0.75$ (cf. Alfaro and Huelsenbeck 2006). Adopting the concept of a selectivity index (reviewed by Manly et al. 2002), we defined relative prevalence, $R P$, of covariate $X$ in the credible set as $R P=\left(x_{c} / n_{c}\right) /\left(x_{a} / n_{a}\right)$, where $0 \leq R P \leq\left(x_{a} / n_{a}\right)^{-1}, n_{c}=$ the number of models in the credible set, $n_{\text {all }}=$ total number of models in the model set (163 in our study), $x_{c}=$ number of models in credible set that contain covariate $X$, and $x_{\text {all }}=$ number of models in entire model set that contain covariate $X$ (64 in our study). $R P$ $=1$ indicates that the covariate is represented in the credible set at a frequency expected by chance. A value of $R P<1$ indicates under-representation, and $R P>1$ over-representation. Instead of relying on binary dichotomies such as those involved in traditional significance tests, we judged the strength of a 
covariate's effect based collectively on the magnitude of its pvalue, standardized coefficient, and standard error (Amrhein et al. 2019, Hurlbert et al. 2019) with strong relationships denoted by low $\mathrm{p}$ values $(<<0.05)$ with large, precise coefficients.

To assess contributions of explanatory variables to top-ranking models, we conducted analysis of deviance using the car package (Fox and Weisberg 2019). Residual diagnostics were assessed with the DHARMa package (Hartig 2019). We evaluated model classification accuracy using area under the receiver-operating curve (AUC). AUC may yield unrealistically high assessments of model performance for use-availability data with a low proportion of detections relative to available points (Sofaer et al. 2019). Thus, we also computed normalized area under the precision-recall curve (AUC-PR) using R package PRROC (Grau et al. 2015). Normalized AUC-PR ranges from 0 (worst performance possible) to 1 (best performance possible); it offers a more robust measure of model accuracy for data with relatively few detections of use, as it adjusts for skew, can be adjusted for weighted points, and does not incorporate available ( 0$)$ points that are predicted to be 0 (Boyd et al. 2012, Keilwagen et al. 2014, Sofaer et al. 2019).

To address our second objective, we assessed whether the manner in which available points were chosen influenced models of resource selection. Typically in use-availability and related studies, available points are chosen at random from a study site, home range, or radius around a focal resource (Thomas and Taylor 2006, Iturbide et al. 2015). However, detection for Red-tailed Hawks and most American Kestrels in our study was limited to sites with suitable perching substrates. In the context of species distribution modeling, species detections may be biased due, e.g., to greater sampling effort in more accessible areas (Phillips et al. 2009). Although our sampling was conducted systematically on transects, the constraints imposed on our detections by perch availability presumably would not be reflected in a set of available points selected randomly from across the width of each transect. Instead, random selection of available points that reflects constraints in sampling of species detections may improve model performance (Phillips et al. 2009, Hanberry et al. 2012). Consequently, we generated two types of available points: completely random, and random subject to biological constraints (hereafter, constrained random). For the former type, we selected points randomly from all landcover classes within each species' respective distance threshold. Red-tailed Hawks and American Kestrels hunt primarily from perches. Hence, constrained random points were selected randomly from available perching substrates (i.e., Treeperim, Treelines, edges of woodlots, Utility, Bildstein 1978, Bildstein and Collopy 1987, Bechard and Swem 2002, Preston and Beane 2009). For each species, we selected available points (completely random, constrained random) at each of two scales to mimic $2^{\text {nd }}$ and $3^{\text {rd }}$-order selection (Johnson 1980): across all transects in our study landscape $(1184 \mathrm{~km})$, and within each transect $(29-47 \mathrm{~km})$. Thus, we considered a total of 2 types of available points $\times 2$ scales $=4$ sets of models for each species, for a total of 8 sets of models.

\section{RESULTS}

We detected 319 raptors of 9 species over $1184 \mathrm{~km}$ of transects (Table 2). Of these, 191 belonged to our target species (Table 2). Ninety percent of perched Red-tailed Hawks were observed in trees, and $70 \%$ of perched American Kestrels were observed on utility lines. None of the kestrels included in the analysis were hovering at the time of detection. Landcover was predominantly agricultural, with most of the sampled area in fields without cover crops $(53.6 \%-91.4 \%)$, or in fields with cover crops $(1.5 \%-12.5 \%)$. Transects were rural, with small amounts devoted to developed areas $(1.4 \%-6.5 \%)$. Permanent herbaceous cover (1.4\%-9.8\%) and woodlands $(0.6 \%-20.9 \%)$ occurred primarily as small patches.

Table 2. Summary of raptor species seen on $1184 \mathrm{~km}$ of transects driven in west-central Indiana, U.S.A., in January-April 2018 and 2019.

\begin{tabular}{|c|c|c|c|c|c|}
\hline Raptor Species & & 2018 & 2019 & Total & $\begin{array}{l}\text { Included in } \\
\text { model }^{\dagger}\end{array}$ \\
\hline $\begin{array}{l}\text { American } \\
\text { Kestrel }^{\dagger}\end{array}$ & Falco sparverius & 24 & 36 & 60 & 43 \\
\hline $\begin{array}{l}\text { Red-tailed } \\
\text { Hawk }^{\dagger}\end{array}$ & Buteo jamaicensis & 43 & 88 & 131 & 72 \\
\hline $\begin{array}{l}\text { Rough-legged } \\
\text { Hawk }\end{array}$ & Buteo lagopus & 5 & 2 & 7 & -- \\
\hline $\begin{array}{l}\text { Northern } \\
\text { Harrier }\end{array}$ & Circus hudsonius & 6 & 4 & 10 & -- \\
\hline Turkey Vulture & Cathartes aura & 38 & 48 & 86 & -- \\
\hline Cooper's Hawk & Accipter cooperii & -- & 9 & 9 & -- \\
\hline Bald Eagle & $\begin{array}{l}\text { Haliaeetus } \\
\text { leucocephalus }\end{array}$ & 7 & 2 & 9 & -- \\
\hline $\begin{array}{l}\text { Red-shouldered } \\
\text { Hawk }\end{array}$ & Buteo lineatus & -- & 2 & 2 & -- \\
\hline $\begin{array}{l}\text { Great-horned } \\
\text { Owl }\end{array}$ & Bubo virginianus & -- & 1 & 1 & -- \\
\hline Unidentified & & 2 & 2 & 4 & -- \\
\hline Total & & 125 & 194 & 319 & 115 \\
\hline
\end{tabular}

Multicollinearity was not a concern; none of the predictors included in the eight global models had variance inflation factors $>2$. For all combinations of species, scales, and types of available points, global models failed to receive support as the AICc-best model. Indeed, in seven of eight model sets considered, the global model was 4 AIC units from the best model. Hence, global models were not considered further.

\section{American Kestrels}

For American Kestrels, classification accuracy of top models was greater when available points were chosen completely at random, with AUC (normalized AUC-PR) of 0.88-0.91 (0.81-0.84) compared to $0.70(0.52-0.53)$ for models with available points constrained by potential perches (Table 3 ). When available points were selected randomly at the transect scale, 13 of 163 candidate models had a collective weight of evidence of 0.75 (Table 3 ). Cover-cropped fields and utility lines were the only two variables to be represented more frequently than expected in the credible set (Table 3). All 13 of these models included overwhelmingly strong negative relationships with distance to utility lines and, to a lesser extent, cover-cropped fields (Table 4). For the best model, a 1 SD increase in distance to utility lines $(598 \mathrm{~m})$ reduced odds of relative kestrel use to essentially zero, whereas 1 SD increases in distance to cover crops $(1201 \mathrm{~m})$ and permanent herbaceous cover $(560 \mathrm{~m})$ reduced odds of relative use to 0.48 and 0.55 , respectively, compared to odds at mean values. For available points constrained by hunting mode at the transect scale, 17 
Table 3. Summary of the top candidate models and relative prevalence of covariates in the credible set ( $\geq 0.75$ AIC weight) for each species $\mathrm{x}$ scale $\mathrm{x}$ availability combination constructed to assess raptor resource selection in west-central Indiana, U.S.A. Area under the receiver operating curve (AUC) and normalized area under the precision-recall curve (AUCNPR) are reported for the top model in each set. Abbreviations: RTHA = Red-tailed Hawk (Buteo jamaicensis), AMKE $=$ American Kestrel $($ Falco sparverius $), \mathrm{R}=$ available points selected randomly, and $\mathrm{CR}=$ available points constrained by hunting mode. Definitions of habitat and landcover variables are given in Table 1; logistic regressions were conducted on standardized distances. Maximum value possible for relative prevalence of a covariate in the credible set $=2.55$, minimum value possible $=0$.

\begin{tabular}{|c|c|c|c|c|c|c|c|c|c|c|c|c|c|}
\hline \multirow[b]{2}{*}{ Species } & \multirow{2}{*}{$\begin{array}{l}\text { Model } \\
\text { Scale }\end{array}$} & \multirow[b]{2}{*}{ Available } & \multirow{2}{*}{$\begin{array}{c}\# \\
\text { Models }\end{array}$} & \multirow[t]{2}{*}{ AUC } & \multirow[t]{2}{*}{ AUCNPR } & \multicolumn{8}{|c|}{ Relative Prevalence in Credible Sets } \\
\hline & & & & & & Cover & NoCover & PermHab & Woods & Dev & Utility & Treeline & Treeperim \\
\hline \multirow[t]{4}{*}{ AMKE } & Transect & $\mathrm{CR}$ & 17 & 0.7 & 0.52 & 2.55 & 2.55 & 0.6 & 0.9 & 0.45 & 0.75 & 0.45 & 0.75 \\
\hline & & $\mathrm{R}$ & 13 & 0.91 & 0.84 & 2.55 & 0.98 & 0.59 & 0.98 & 0 & 2.55 & 0.59 & 0.78 \\
\hline & Landscape & CR & 16 & 0.7 & 0.53 & 2.55 & 2.55 & 0.64 & 0.96 & 0.48 & 0.96 & 0.32 & 0.64 \\
\hline & & $\mathrm{R}$ & 12 & 0.88 & 0.81 & 2.55 & 0.85 & 0.85 & 0.42 & 0.42 & 2.55 & 0.21 & 1.27 \\
\hline \multirow[t]{4}{*}{ RTHA } & Transect & $\mathrm{CR}$ & 30 & 0.69 & 0.52 & 0.34 & 0.93 & 0.85 & 1.36 & 1.36 & 2.55 & 0.42 & 0.51 \\
\hline & & $\mathrm{R}$ & 27 & 0.76 & 0.64 & 0.38 & 0.57 & 1.13 & 2.55 & 1.32 & 0.47 & 0.47 & 1.6 \\
\hline & Landscape & CR & 25 & 0.72 & 0.56 & 0.41 & 0.82 & 1.12 & 1.94 & 0.92 & 2.55 & 0.41 & 0.51 \\
\hline & & $\mathrm{R}$ & 25 & 0.77 & 0.64 & 0.31 & 0.51 & 1.02 & 2.55 & 1.83 & 0.61 & 0.71 & 1.32 \\
\hline
\end{tabular}

candidate models had a collective weight of evidence of 0.76 (Table 3). Cover-cropped and non-cover-cropped fields were the only two variables to be represented more frequently than expected in the credible set (Table 3). All 17 of these models included a strong negative relationship with distance to covercropped fields and, to a lesser extent, non-cover-cropped fields (Table 3, 4). In the best model a $1 \mathrm{SD}$ increase in distance to cover crops $(1111 \mathrm{~m})$ and fields without cover crops $(57 \mathrm{~m})$ reduced odds of relative use to 0.44 and 0.49 , respectively.

When available points were selected randomly at the landscape scale, 12 candidate models had a collective weight of evidence of 0.78 (Table 3 ). Cover-cropped fields and utility lines were the only two variables to be represented more frequently than expected in the credible set, and development was not included (Table 3). All 12 models included strong negative relationships between detections and distance to cover-cropped fields and utility lines, with effects that were similar in magnitude to those for the corresponding model at the transect scale (Table 4). For available points constrained by hunting mode at the landscape scale, 16 candidate models exhibited a collective weight of evidence of 0.76 (Table 3). Cover-cropped and non-cover-cropped fields were the only two variables to be represented more frequently than expected in the credible set (Table 3). All 16 models incorporated a strong negative relationship with distance to cover-cropped and, to a lesser degree, non-cover-cropped fields, with effects similar in size to the constrained random models at the transect scale (Table 3, 4). To check that models discriminating between fields with and without cover crops were necessary, we replaced Cover and NoCover variables in top-ranked models with nearest distance to agricultural fields (Agriculture) and refit the models. Models with Agriculture were always inferior to models with Cover and NoCover (AICc $>8$ for all comparisons) and were not considered further.

\section{Red-tailed Hawks}

For Red-tailed Hawks considered at both scales and for both types of available points, AICc-best models exhibited moderate classification accuracy, with AUC (normalized AUC-PR) of
0.69-0.77 (0.52-0.66; Table 3). For available points selected randomly at the transect scale, 27 of the 163 candidate models displayed a collective weight of evidence of 0.75 (Table 3). Distance to woodlots, development, and tree perimeters occurred more frequently than random, with distance to woodlots equivalent to the maximum possible value (Table 3 ). All 27 models included a strong negative relationship with distance to woodlots. A negative effect of distance to tree perimeter occurred in 17 models including the top 3 , and a negative relationship with distance to development and permanent herbaceous cover occurred in 14 and 12 of the 27 models, respectively (Table 3, 4). Relative to mean values, a 1 SD increase in distance to woods (191 $\mathrm{m})$ and tree perimeter $(241 \mathrm{~m})$ reduced odds of relative use to 0.20 and 0.67 . For available points constrained by potential perches at the transect scale, 30 candidate models had a collective weight of evidence of 0.76 (Table 3). Distance to utility lines, development, and woodlots occurred more frequently than random, with distance to utility lines occurring at the maximum possible value (Table 3). All 30 top models included strong negative relationships between use and distance to utility lines, while 16 of the top models included a strong positive relationship with distance to woodlots and important but weaker effects of distance to development (Table 3,4). Relative to mean values, a $1 \mathrm{SD}$ change in these three variables $(162,115$, and $566 \mathrm{~m}$, respectively) for the best model resulted in odds of $1.19,1.22$, and 0.64 , respectively.

For available points selected randomly at the landscape scale, 25 candidate models exhibited a collective weight of evidence of 0.76 (Table 3). As with the transect scale, distance to woodlots, development, and tree perimeters occurred more frequently than random, with distance to woodlots equivalent to the maximum possible value (Table 3). A strong negative relationship with distance to woodlot was found in all 25 models. As with the transect scale, a negative relationship with distance to development was included in 18 of the 25 models (Table 3, 4). For available points constrained by potential perches at the landscape scale, 25 models had a collective weight of evidence of 0.75 (Table $3)$. Distance to utility lines and woodlots occurred more frequently than random, with distance to utility lines equivalent 
Table 4. TEST Regression coefficients ( \pm Standard Error) for the top 2-3 resource selection models for each species, as determined with $\triangle$ AICc. Abbreviations: RTHA $=$ Red-tailed Hawk (Buteo jamaicensis), AMKE $=$ American Kestrel $($ Falco sparverius $)$, R $=$ available points selected randomly, $\mathrm{CR}=$ available points constrained by hunting mode. Definitions of habitat and landcover variables are given in Table 1; logistic regressions were conducted on standardized distances.

\begin{tabular}{|c|c|c|c|c|c|c|c|c|c|c|c|}
\hline Species & Scale & Available & Model & Cover & NoCover & PermHab & Woods & Dev & Utility & Treeline & Treeperim \\
\hline \multirow[t]{9}{*}{ AMKE } & Transect & $\mathrm{CR}$ & 1 & $\begin{array}{l}-0.81 \\
(0.28)^{* *}\end{array}$ & $\begin{array}{l}-0.71 \\
(0.36)^{* *}\end{array}$ & & $\begin{array}{l}0.29 \\
(0.12)^{* *}\end{array}$ & & & & $\begin{array}{l}-0.34 \\
(0.22)^{*}\end{array}$ \\
\hline & & & 2 & $\begin{array}{l}-0.73 \\
(0.28)^{* *}\end{array}$ & $\begin{array}{l}-0.71 \\
(0.36)^{* *}\end{array}$ & $\begin{array}{l}-0.40 \\
(0.26)^{*}\end{array}$ & $\begin{array}{l}0.29 \\
(0.11)^{* *}\end{array}$ & & & & \\
\hline & & $\mathrm{R}$ & 1 & $\begin{array}{l}-0.73 \\
(0.29)^{* *}\end{array}$ & & $\begin{array}{l}-0.59 \\
(0.33)^{* *}\end{array}$ & $\begin{array}{l}0.50 \\
(0.20)^{* *}\end{array}$ & & $\begin{array}{l}-43.77 \\
(7.39)^{* *}\end{array}$ & & \\
\hline & Landscape & $\mathrm{CR}$ & 1 & $\begin{array}{l}-0.76 \\
(0.29)^{* *}\end{array}$ & $\begin{array}{l}-0.79 \\
(0.40)^{* *}\end{array}$ & $\begin{array}{l}-0.37 \\
(0.25)\end{array}$ & $\begin{array}{l}0.29 \\
(0.13)^{*}\end{array}$ & & & & \\
\hline & & & 2 & $\begin{array}{l}-0.83 \\
(0.30)^{* *}\end{array}$ & $\begin{array}{l}-0.80 \\
(0.40)^{* *}\end{array}$ & & $\begin{array}{l}0.27 \\
(0.13)^{*}\end{array}$ & & & & $\begin{array}{l}-0.30 \\
(0.21)\end{array}$ \\
\hline & & & 3 & $\begin{array}{l}-0.73 \\
(0.28)^{* *}\end{array}$ & $\begin{array}{l}-0.72 \\
(0.38)^{* *}\end{array}$ & & & & $\begin{array}{l}-0.62 \\
(0.55)\end{array}$ & & \\
\hline & & $\mathrm{R}$ & 1 & $\begin{array}{l}-0.86 \\
(0.30)^{* *}\end{array}$ & $\begin{array}{l}-0.38 \\
(0.28)^{*}\end{array}$ & & & & $\begin{array}{l}-12.11 \\
(2.10)^{* *}\end{array}$ & & $\begin{array}{l}-0.48 \\
(0.28)^{* *}\end{array}$ \\
\hline & & & 2 & $\begin{array}{l}-0.78 \\
(0.30)^{* *}\end{array}$ & $\begin{array}{l}-0.37 \\
(0.28)^{*}\end{array}$ & $\begin{array}{l}-0.54 \\
(0.32)^{*}\end{array}$ & & & $\begin{array}{l}-12.13 \\
(2.10)^{* *}\end{array}$ & & \\
\hline & & & 3 & $\begin{array}{l}-0.77 \\
(0.29)^{* *}\end{array}$ & & & & & $\begin{array}{l}-12.24 \\
(2.10)^{* *}\end{array}$ & & $\begin{array}{l}-0.41 \\
(0.26)^{*}\end{array}$ \\
\hline \multirow[t]{11}{*}{ RTHA } & Transect & $\mathrm{CR}$ & 1 & & & & $\begin{array}{l}-0.44 \\
(0.25)^{* *}\end{array}$ & $\begin{array}{l}0.20 \\
(0.10)^{*}\end{array}$ & $\begin{array}{l}0.18 \\
(0.05)^{* *}\end{array}$ & & \\
\hline & & & 2 & & & $\begin{array}{l}-0.23 \\
(0.19)\end{array}$ & $\begin{array}{l}-0.33 \\
(0.26)\end{array}$ & $\begin{array}{l}0.22 \\
(0.10)^{* *}\end{array}$ & $\begin{array}{l}0.18 \\
(0.05)^{* *}\end{array}$ & & \\
\hline & & & 3 & & & $\begin{array}{l}-0.32 \\
(0.18)^{* *}\end{array}$ & & $\begin{array}{l}0.20 \\
(0.10)^{*}\end{array}$ & $\begin{array}{l}0.20 \\
(0.05)^{* *}\end{array}$ & & \\
\hline & & $\mathrm{R}$ & 1 & & & & $\begin{array}{l}-1.59 \\
(0.43)^{* *}\end{array}$ & & & & $\begin{array}{l}-0.40 \\
(0.20)^{* *}\end{array}$ \\
\hline & & & 2 & & & $\begin{array}{l}-0.31 \\
(0.25)\end{array}$ & $\begin{array}{l}-1.39 \\
(0.45)^{* *}\end{array}$ & & & & $\begin{array}{l}-0.36 \\
(0.20)^{* *}\end{array}$ \\
\hline & & & 3 & & & & $\begin{array}{l}-1.51 \\
(0.43)^{* *}\end{array}$ & $\begin{array}{l}-0.20 \\
(0.20)\end{array}$ & & & $\begin{array}{l}-0.30 \\
(0.21)\end{array}$ \\
\hline & Landscape & $\mathrm{CR}$ & 1 & & & & $\begin{array}{l}-0.48 \\
(0.26)^{* *}\end{array}$ & & $\begin{array}{l}0.19 \\
(0.04)^{* *}\end{array}$ & & \\
\hline & & & 2 & & & & $\begin{array}{l}-0.54 \\
(0.27)^{* *}\end{array}$ & $\begin{array}{l}0.16 \\
(0.11)\end{array}$ & $\begin{array}{l}0.19 \\
(0.04)^{* *}\end{array}$ & & \\
\hline & & & 3 & & $\begin{array}{l}-0.14 \\
(0.12)\end{array}$ & & $\begin{array}{l}-0.52 \\
(0.27)^{* *}\end{array}$ & & $\begin{array}{l}0.22 \\
(0.04)^{* *}\end{array}$ & & \\
\hline & & $\mathrm{R}$ & 1 & & & $\begin{array}{l}-0.34 \\
(0.26)\end{array}$ & $\begin{array}{l}-1.97 \\
(0.56)^{* *}\end{array}$ & $\begin{array}{l}-0.45 \\
(0.22)^{* *}\end{array}$ & & & \\
\hline & & & 2 & & & & $\begin{array}{l}-2.22 \\
(0.53)^{* *}\end{array}$ & $\begin{array}{l}-0.49 \\
(0.22)^{* *}\end{array}$ & & & \\
\hline $\begin{array}{l}* 0.05< \\
* * p \leq c\end{array}$ & & & & & & & & & & & \\
\hline
\end{tabular}

to the maximum possible value (Table 3). Similar to the transect scale, all top models included a strong positive relationship with distance to utility lines, and 19 of 25 models included a negative relationship with distance to woodlots (Table 3,4).

\section{DISCUSSION}

Although Andres (1994) found that American Kestrels in Kentucky did not use crop fields, American Kestrels within our study site were strongly influenced by access to hunting habitat. In all of our top constrained availability models, American Kestrels were associated with both cover-cropped and non-covercropped fields. Unlike Kentucky, permanent herbaceous cover in our study area was sparse, and much of it was positioned along roads. The inclusion of permanent herbaceous cover in several of our top kestrel models was noteworthy, as roadsides can serve as important habitat for grassland invertebrates and small mammals, especially in intensively agricultural regions (Getz et al. 1978, Adams and Geis 1983, Adams 1984, Evans et al. 2016). During our survey period, cover-cropped fields had a similar vegetative profile to roadside habitats and could have aided small mammal dispersal into the fields, thus attracting kestrels. Although they did not influence raptor abundance in Arkansas (Bobowski et al. 2014), untilled fields without cover crops also likely harbor prey available to kestrels. Within the surveyed counties, an estimated $26-83 \%$ of corn and $51-90 \%$ of soybean fields were untilled following the harvest and prior to our surveys (Indiana State Department of Agriculture 2019). Deer mice (Peromyscus maniculatus) and, to a lesser extent, prairie voles (Microtus ochrogaster) use reduced tillage row-crop fields within our study area during winter (Berl et al. 2017), and additional 
species of small mammals move into fields during the growing season (Abercrombie et al. 2017, Berl et al. 2018). As we only surveyed each transect once a year, we were unable to assess whether use of cover-cropped and non-cover-cropped agricultural fields changed over the course of the winter. Hence, future studies should investigate temporal variation in habitat use.

Unlike kestrels, fewer top models for Red-tailed Hawks incorporated agricultural landcover. Instead, Red-tailed Hawks associated most closely with woodlots. Although Red-tailed Hawks used utility poles and wires more than trees in Florida (Pearlstine et al. 2006) and Arkansas (Worm et al. 2013), use of trees and woodlots has been widely reported (Schnell 1968, Shupe and Collins 1983, Bohall and Collopy 1984, Leyhe and Ritchison 2004, Ingold 2010, Bobowski et al. 2014). Indeed, the association between Red-tailed Hawks and woodlots in the Midwest has been well documented; woodlots are used throughout the year by both hunting and nesting individuals (Schnell 1968, Bildstein 1978, Petersen 1979, Ingold 2010). In addition to defending woodlots, Red-tailed Hawks may encounter increased abundances of small mammals at the border between woodlots and fields (Bildstein 1978, Cummings and Vessey 1994, García et al. 1998, Śálek et al. 2010). The potential for high prey encounter rates as well as the abundance of perches along woodlot edges likely increases Redtailed Hawk hunting efficiency, further directing their presence toward woodlots. Nevertheless, as our study area lacked large expanses of woodland, future studies should investigate the potential differences in habitat use among areas with varying availability of woodlands.

When hunting, American Kestrels demonstrated an increased presence near cover-cropped fields, whereas Red-tailed Hawks exhibited an increased affinity for available perches and nonagricultural habitats. In light of these results, producers could encourage further kestrel hunting of cover-cropped fields by erecting nest boxes and artificial perches as well as managing permanent herbaceous cover (Toland and Elder 1987, Valdez et al. 2000, Shave and Lindell 2017, Shave et al. 2018a, Zagorski and Swihart 2020). Supplementing available perches, particularly in the field interior, could increase the area kestrels can easily hunt, while attracting breeding pairs could increase predation pressure during planting and germination when voles consume seeds and newly sprouted crops (Fisher et al. 2014, Shave et al. 2018a, 2018b, Prieur and Swihart 2020b,c). Moreover, managing permanent herbaceous cover to increase invertebrate diversity could provide kestrels with more insect prey and increase crop pollination services (Clark et al. 2005, Marshall et al. 2006, Hopwood 2008, Garibaldi et al. 2014, Evans et al. 2016).

Roadside counts are subject to at least three potential biases. Specifically, the placement of roads, and thus transects, may not be representative of the surrounding landcover, detectability may vary depending on the structure of vegetation along roads, and double counting could occur (Millsap and LeFranc 1988). We believe these sources of bias were minimal in our study. County roads in our study were uniformly spaced and thus representative of the surrounding landcover. In addition, landcover in this intensive agroecosystem exhibited little variability that would affect detectability of raptors (USDA NASS 2019b, Zagorski 2019). Double-counting was likely not an issue because both study species tend to winter on or near their breeding territory (Petersen
1979, Bird and Palmer 1988). Although not quantified for Redtailed Hawks, the mean diameter of American Kestrel winter territories was 1.4-3.5 km (Bird and Palmer 1988), which is smaller than the shortest distance between our transects.

Scale did not greatly affect the inclusion of habitat variables into top models. One exception was observed for American Kestrels, which reduced their use of woodlots at the transect scale but not at the landscape scale (Table 4). As North America's smallest diurnal raptor, kestrels are susceptible to predation and competition with other raptors, including Red-tailed Hawks, Sharp-shinned Hawks (Accipter striatus) and Cooper's Hawks (Accipter cooperii), all of which are associated with woodlots (Smallwood and Bird 2002, Farmer et al. 2006). Among wintering kestrels in Pennsylvania, avian predators were responsible for $62 \%$ of kestrel mortality (Farmer et al. 2006). Therefore, by reducing their use of woodlots at a finer scale, kestrels may have chosen foraging sites that reduced risk of predation and competition.

Resource selection models based on biologically constrained available points tended to yield worse predictive accuracy than models using available points drawn completely at random, a pattern also observed by Cerasoli et al. (2017) for species distribution models. Reduced classification accuracy follows logically from the inclusion of prior knowledge into selection of available points. However, selection of available points from the suite of available perch sites provided a more biologically relevant comparison for species that are known to hunt predominantly from perches. By extension, available points constrained in this manner more closely aligned with detections, making it more difficult for the models to classify points accurately but enabling us to identify more subtle features that influenced use of foraging sites. In particular, the method of selection of available points influenced the category (i.e., perch or landcover) of habitat variables deemed important to Red-tailed Hawks and American Kestrels.

For kestrels, utility poles and lines were only included in the best models created with randomly selected available points, and the magnitude of selection for this feature was 60 (transect) and 15 (landscape) times greater than for the next most important variable in these models (cover crops, Table 4). Such an outcome is unsurprising when considering prior knowledge about kestrels, as they often hunt from utility lines (Andres 1994, Ingold 2010, Bobowski et al. 2014). In our study, 30 of 43 detections were from utility lines. Thus, the inclusion in models of available points chosen randomly from all possible points confirmed our understanding of the importance of utility lines as perch sites for kestrels in agricultural regions. Importantly, models that relied on available points drawn solely from possible perch sites revealed reduced use of woodland perches and an increased use of perch sites near fields lacking cover crops (Table 4). Constraining available points to possible perch sites thus shed light on additional features of perch site use by kestrels that would not have been evident with the more conventional (completely random) approach to modeling use-availability.

The influence of competing definitions of availability was more nuanced for Red-tailed Hawks. In particular, the two methods of generating available points yielded best models that diverged in their associations with development. In constrained availability models, Red-tailed Hawks reduced their use (transect scale) or 
were neutral (landscape scale) to development, whereas in random availability models they tended to associate with development. At both scales, constrained availability resulted in a stronger signal of aversion to development. Discrepancies in expected associations with development resulted from altered distributions of distances chosen with the two methods of defining availability. Mean observed distance to development was $93 \mathrm{~m}$. For available sites constrained to potential perches, mean distances to development were less than mean observed distance, (i.e., $69 \mathrm{~m}$ for transect, $79 \mathrm{~m}$ for landscape), whereas mean distances for available sites selected randomly (i.e., $138 \mathrm{~m}$ for transect, $165 \mathrm{~m}$ for landscape) were greater than the observed mean. This example thus illustrates how the method of selection of available points can impact not only the inclusion of variables, but also the direction of association. For Red-tailed Hawks, the constrained availability models, by virtue of selecting only from available perches, highlighted habitat associations, particularly reduced use of development and utility lines, that we believe more accurately reflect perch-site use than associations conveyed by the random models.

When modeling resource selection, multiple definitions of availability potentially can yield complementary insights. However, consideration of constrained availability may not be feasible for under-studied species or those species for which discrete, biologically important habitat features are not easily identified on the landscape. To place intelligent constraints on choice of available points necessitates some knowledge of the species' biology as it relates to the resource in question. Stewart et al. (2013) modified a previously developed model to constrain selection of available points when testing selection of habitat edges by grizzly bears (Ursus arctos). We used knowledge of hunting behavior by American Kestrels and Red-tailed Hawks to constrain our selection of available points to potential perch sites. However, for species with a paucity of biological information, identification of potential features on which to constrain choices of availability may not be obvious, in which case availability determined completely at random is most appropriate. Even for well-studied species, constraining available points to biologically relevant and spatially discrete habitat features can pose a challenge when these habitat features are not easily mapped, especially if spatial projections of model predictions are desired. Employing constrained availability in models of resource selection will therefore work best for well-studied species that utilize spatially distinct and biologically relevant habitat features amenable to mapping, such as with some birds (e.g., perching and nesting sites), bats (e.g., roosting structures), or amphibians (e.g., vernal pools).

Responses to this article can be read online at: https://www.ace-eco.org/issues/responses.php/1719

\section{Acknowledgments:}

We thank C. Conigliaro and D. Hixon for their assistance with field work. Comments from J. Dunning Jr., A. Janke, the Subject Editor, and 2 anonymous reviewers improved the manuscript. Our work was supported by the U.S. Department of Agriculture Natural Resources
Conservation Service [grant number 68-3A75-18-127], the U.S. Department of Agriculture National Institute of Food and Agriculture [Hatch project 1014271], and the Purdue University Department of Forestry and Natural Resources. The data that support the findings of this study are openly available in the Purdue University Research Repository at (https://purr.purdue.edu, DOI: 10.4231/83SG-7P52).

\section{LITERATURE CITED}

Abercrombie, S. A., J. L. Berl, E. A. Flaherty, and R. K. Swihart. 2017. Seasonal foraging by forest mice enhances loss of weed seeds from crop-field edges. Northeastern Naturalist 24:5-17. https:// doi.org/10.1656/045.024.0sp803

Adams, L. W. 1984. Small mammal use of an interstate highway median strip. Journal of Applied Ecology 21:175-178. https://doi. org/10.2307/2403045

Adams, L. W., and A. D. Geis. 1983. Effects of roads on small mammals. Journal of Applied Ecology 20:403-415. https://doi. org/10.2307/2403516

Alfaro, M. E., and Huelsenbeck. 2006. Comparative performance of Bayesian and AIC-based measures of phylogenetic model uncertainty. Systematic Biology 55:89-96. https://doi.

org/10.1080/10635150500433565

Amrhein, V., S. Greenland, and B. McShane. 2019. Retire statistical significance. Nature 567:305-307. https://doi. org/10.1038/d41586-019-00857-9

Andres, B. A. 1994. Density and habitat use of hawks wintering at the bluegrass region of Kentucky. The Kentucky Warbler 70:57-63.

Ardia, D. R., and K. L. Bildstein. 2001. Sex-related differences in habitat use in wintering American Kestrels. The Auk 118:746-750. https://doi.org/10.1093/auk/118.3.746

Babińska-Werka, J. 1979. Effects of common vole on alfalfa crop. Acta Theriologica 24:281-297. https://doi.org/10.4098/AT. arch.79-29

Baker, J. A., and R. J. Brooks. 1981. Distribution patterns of raptors in relation to density of meadow voles. The Condor 83:42-47. https://doi.org/10.2307/1367598

Bartoń, K. 2019. MuMIn: Multi-model inference. R package version 1.43.6. [online] URL: https:/CRAN.R- project.org/ package $=$ MuMIn.

Bechard, M. J. 1982. Effect of vegetative cover on foraging site selection by Swainson's Hawk. The Condor 84:153-159. https:// doi.org/10.2307/1367658

Bechard, M. J., and T. R. Swem. 2002. Rough-legged Hawk (Buteo lagopus). Cornell Lab of Ornithology, Ithaca, New York, USA.

Benson, J. F. 2013. Improving rigour and efficiency of useavailability habitat selection analyses with systematic estimation of availability. Methods in Ecology and Evolution 4:244-251. https://doi.org/10.1111/2041-210x.12006

Berl, J. L., E. A. Flaherty, B. J. Danielson, K. F. Kellner, and R. K. Swihart. 2017. Winter ecology of prairie deer mice (Peromyscus 
maniculatus bairdii) in cultivated habitats: Implications for agricultural ecosystem services. Agriculture, Ecosystems, and Environment 249:130-136. https://doi.org/10.1016/j.agee.2017.08.019

Berl, J. L., K. F. Kellner, E. A. Flaherty, and R. K. Swihart. 2018. Spatial variation in density of white-footed mice along edges in fragmented habitat. American Midland Naturalist 179:38-50. https://doi.org/10.1674/0003-0031-179.1.38

Best, L. B., H. Campa III, K. E. Kemp, R. J. Robel, M. R. Ryan, J. A. Savidge, H. P. Weeks Jr., and S. R. Winterstein. 1997a. Avian abundance in CRP and crop fields during winter in the Midwest. The American Midland Naturalist 139:311-324. https://doi.org/ https://doi.org/10.1674/0003-0031(1998)139[0311:aaicac]2.0.co;2

Best, L. B., H. Campa III, K. E. Kemp, R. J. Robel, M. R. Ryan, J. A. Savidge, H. P. Weeks Jr., and S. R. Winterstein. 1997b. Bird abundance and nesting in CRP fields and cropland in the Midwest: a regional approach. Wildlife Society Bulletin 25:864-877.

Bildstein, K. L. 1978. Behaviorial ecology of Red-tailed Hawks (Buteo jamaicensis), Rough-legged Hawks (B. lagopus), Northern Harriers (Circus cyaneus), American Kestrels (Falco sparverius) and other raptorial birds wintering in south central Ohio. Ph.D., The Ohio State University, Columbus, Ohio, USA.

Bildstein, K. L., and M. W. Collopy. 1987. Hunting behavior of Eurasian (Falco tinnunculus) and American Kestrels (Falco sparverius): A review. Pages 66-82 in D. M. Bird and R. Bowman, editors. The Ancestral Kestel. Raptor Research Foundation, Inc. and Macdonald Raptor Research Centre of McGill University.

Bird, D. M., and R. S. Palmer. 1988. American Kestrel. Pages 253-290 in R. S. Palmer, editor. Handbook of North American birds. Yale University Press, New Haven, CT.

Boano, G., and R. Toffoli. 2002. A line transect survey of wintering raptors in the western Po plain of northern Italy. Journal of Raptor Research 36:128-135.

Bobowski, M. M., V. Rolland, and T. S. Risch. 2014. Abundance and distribution of overwintering Red-tailed Hawks and American Kestrels in an agricultural landscape in northeastern Arkansas. Journal of Raptor Research 48:273-279. https://doi. org/10.3356/JRR-13-54.1

Bohall, P. G., and M. W. Collopy. 1984. Seasonal abundance, habitat use, and perch sites of four raptor species in north-central Florida. Journal of Field Ornithology 55:181-189.

Boyd, K., V. Santos Costa, J. Davis, and C. D. Page. 2012. Unachievable region in precision-recall space and its effect on empirical evaluation. Page Proceedings of the 29th International Conference on Machine Learning. Edinburgh, Scotland.

Bunn, A. G., W. Klein, and K. L. Bildstein. 1995. Time-of-day effects on the numbers and behavior of non-breeding raptors seen on roadside surveys in eastern Pennsylvania. Journal of Field Ornithology 66:544-552.

Butet, A., N. Michel, Y. Rantier, V. Comor, L. Hubert-Moy, J. Nabucet, and Y. Delettre. 2010. Responses of Common Buzzard (Buteo buteo) and Eurasian Kestrel (Falco tinnunculus) to land changes in agricultural landscapes of western France. Agriculture,
Ecosystems, and Environment 138:152-159. https://doi.org/10.1016/ j.agee.2010.04.011

Carman, S. F. 2013. Indiana forest management history and practices. Pages 12-23 in R. K. Swihart, M. Saunders, R. A. Kalb, G. S. Haulton, and C. H. Michler, editors. The Hardwood Ecosystem Experiment: a framework for studying responses to forest management. USDA Forest Service Northern Research Station, Newtown Square, Pennsylvania, USA.

Cerasoli, F., M. Iannella, P. D'Alessandro, and M. Biondi. 2017. Comparing pseudo-absences generation techniques in Boosted Regression Trees models for conservation purposes: A case study on amphibians in a protected area. PLOS ONE 12:e0187589. https://doi.org/10.1371/journal.pone.0187589

Clark, R. G., C. Boutin, B. Jobin, D. J. Forsyth, D. Shutler, J. Y. Leeson, O. Olfert, and A. G. Thomas. 2005. Living on the edge: Field boundary habitats, biodiversity and agriculture. Pages 113-133 in A. G. Thomas, editor. Field boundary habitats: Implications for weed, insect and disease management. Canadian Weed Science Society - Société canadienne de malherbologie, Sainte-Anne-de-Bellevue, Québec, Canada.

Collopy, M. W., and J. R. Koplin. 1983. Diet, capture success, and mode of hunting by female American Kestrels in winter. The Condor 85:369-371. https://doi.org/10.2307/1367081

Conner, L. M., and B. W. Plowman. 2001. Using Euclidean distances to assess nonrandom habitat use. Pages 275-290 in J. J. Millspaugh and J. M. Marzluff, editors. Radio tracking and animal populations. Academic Press, San Diego, CA. https://doi. org/10.1016/B978-012497781-5/50011-6

Conner, L. M., M. D. Smith, and L. W. Burger. 2003. A comparison of distance-based and classification-based analyses of habitat use. Ecology 84:526-531. https://doi.org/10.1890/0012-9658 (2003)084[0526:ACODBA]2.0.CO;2

Conservation Technology Information Center. 2017. Report of the 2016-2017 National Cover Crop Survey. Report of the 2016-17 National Cover Crop Survey., Joint publication of the Conservation Technology Information Center, the North Central Region Sustainable Agriculture Research and Education Program, and the American Seed Trade Association, West Lafayette, Indiana, USA.

Craighead, J. J., and F. C. Craighead. 1956. Hawks, Owls and Wildlife. The Stackpole Company, Harrisburg, Pennsylvania, USA.

Cummings, J. R., and S. H. Vessey. 1994. Agricultural influences on movement patterns of white-footed mice (Peromyscus leucopus). The American Midland Naturalist 132:209-218. https:// doi.org/10.2307/2426575

Dabney, S. M., J. A. Delgado, and D. W. Reeves. 2001. Using winter cover crops to improve soil and water quality. Communications in Soil Science and Plant Analysis 32:1221-1250. https://doi.org/10.1081/CSS-100104110

Ehrenberger, K. A., and J. B. Dunning Jr. 2011. The responses of selected wildlife to macrotopographic enhancements of a Wetland Reserve Program restoration. Proceedings of the Indiana Academy of Science 119:158-169. 
Ellis, K. E., and M. E. Barbercheck. 2015. Management of overwintering cover crops influences floral resources and visitation by native bees. Environmental Entomology 44:999-1010. https://doi.org/10.1093/ee/nvv086

Evans, T. R., M. J. Mahoney, E. D. Cashatt, G. de Snoo, and C. J. M. Musters. 2016. Enhancement of linear agricultural areas to provide invertebrates as potential food for breeding birds. Land 5. https://doi.org/10.3390/land5030026

Fargallo, J. A., J. Padilla-Martínez, J. Viñuela, G. Blanco, I. Torre, P. Vergara, and L. De Neve. 2009. Kestrel-prey dynamic in a mediterranean region: The effect of generalist predation and climatic factors. PLoS ONE 4:e4311. https://doi.org/10.1371/ journal.pone.0004311

Farmer, C. J., and J. P. Smith. 2009. Migration monitoring indicates widespread declines of American Kestrels (Falco sparverius) in North America. Journal of Raptor Research 43:263-273. https://doi.org/10.3356/JRR-08-14.1

Farmer, G. C., K. McCarty, S. Robertson, B. Robertson, and K. L. Bildstein. 2006. Suspected predation by Accipters on radiotracked American Kestrels (Falco sparverius) in eastern Pennsylvania, U.S.A. Journal of Raptor Research 40:294-297. https://doi.org/10.3356/0892-1016(2006)40[294:SPBAOR]2.0.CO;2

Filloy, J., and M. I. Bellocq. 2007. Respuesta de las aves rapaces al uso de la tierra: un enfoque regional. Hornero 22:1-140.

Fisher, B., V. Shelton, and T. Bailey. 2014. Vole control. Page 2. USDA NRCS.

Fithian, W., and T. Hastie. 2013. Finite-sample equivalence in statistical models for presence-only data. The Annals of Applied Statistics 7:1917-1939. https://doi.org/10.1214/13-AOAS667

Fox, J., and S. Weisberg. 2019. An $\{R\}$ companion to applied regression. Third. Sage Publications, Thousand Oaks, California, USA.

Fuller, M. R., and J. A. Mosher. 1981. Methods of Detecting and Counting Raptors: A Review. Pages 235-246 in C. J. Ralph and J. M. Scott, editors. Estimating Numbers of Terrestrial Birds. Cooper Ornithological Society (Allen Press, Inc.), Lawrence, Kansas, USA.

Fuller, M. R., and J. A. Mosher. 1987. Raptor survey techniques. Pages 37-65 in B. A. Giron Pendleton, B. A. Millsap, K. W. Cline, and D. M. Bird, editors. Raptor management techniques. National Wildlife Federation, Washington D.C., USA.

García, F. J., M. Díaz, J. M. de Alba, C. L. Alonso, R. Carbonell, M. L. de Carrión, C. Monedero, and T. Santos. 1998. Edge effects and patterns of winter abundance of wood mice Apodemus sylvaticus in Spanish fragmented forests. Acta Theriologica 43:255-262. https://doi.org/10.4098/AT.arch.98-20

Garibaldi, L. A., L. G. Carvalheiro, S. D. Leonhardt, M. A. Aizen, B. R. Blaauw, R. Isaacs, M. Kuhlmann, D. Kleijn, D. Klein, C. Kremen, L. Morandin, J. Scheper, and R. Winfree. 2014. From research to action: enhancing crop yield through wild pollinators. Frontiers in Ecology and Evolution 12:439-447. https://doi. org/10.1890/130330

Getz, L. L., and E. Brighty. 1986. Potential effects of small mammals in high-intensity agricultural systems in east-central
Illinois, USA. Agriculture, Ecosystems, and Environment 15:39-50. https://doi.org/https://doi.org/10.1016/0167-8809(86)90112-x

Getz, L. L., F. R. Cole, and D. L. Gates. 1978. Interstate roadsides as dispersal routes for Microtus pennsylvanicus. Journal of Mammalogy 59:208-212. https://doi.org/10.2307/1379900

Grande, J. M., P. M. Orozco-Valor, M. S. Liébana, and J. H. Sarasola. 2018. Birds of prey in agricultural landscapes: The role of agriculture expansion and intensification. Pages 197-228 in J. H. Sarasola, J. M. Grande, and J. J. Negro, editors. Birds of Prey: Biology and conservation in the XXI century. Springer. https://doi. org/10.1007/978-3-319-73745-4_9

Grau, J., I. Grosse, and J. Keilwagen. 2015. PRROC: computing and visualizing precision-recall and receiver operating characteristic curves in R. Bioinformatics 31:2595-2597. https:// doi.org/10.1093/bioinformatics/btv153

Griffith, D. R., J. V. Mannering, and W. C. Moldenhaur. 1977. Conservation tillage in the eastern Corn Belt. Journal of Soil and Water Conservation 32:20-28.

Hanberry, B. B., H. S. He, and B. J. Palik. 2012. Pseudoabsence generation strategies for species distribution models. PLoS ONE 7:1-12. https://doi.org/https://doi.org/10.1371/journal.pone.0044486

Hartig, F. 2019. DHARMa: Residual diagnostics for hierarchical (multi-levellmixed) regression models. $\mathrm{R}$ package version 0.2.4. [online] URL: https://CRAN.R-project.org/package=DHARMa.

Hopwood, J. L. 2008. The contribution of roadside grassland restorations to native bee conservation. Biological Conservation 141:2632-2640. https://doi.org/10.1016/j.biocon.2008.07.026

Hurlbert, S. H., R. A. Levine, and J. Utts. 2019. Coup de grâce for a tough old bull: "Statistically significant" expires. The American Statistician 73:352-357. https://doi.org/10.1080/00031305.2018.1543616

Hutto, R. L. 2016. Should scientists be required to use a modelbased solution to adjust for possible distance-based detectability bias? Ecological Applications 26:1287-1294. https://doi.org/ https://doi.org/10.1002/eap.1385

Hutto, R. L. 2017. Reply to Marques et al. (2017): how to best handle potential detectability bias. Ecological Applications 27:1699-1702. https://doi.org/10.1002/eap.1570

Indiana State Department of Agriculture. 2019. Cover crop and tillage transect data. https://www.in.gov/isda/2383.htm.

Ingold, D. J. 2010. Abundance and habitat use of winter raptors on a reclaimed surface mine in southeastern Ohio. Ohio Journal of Science 110:70-76.

Iturbide, M., J. Bedia, S. Herrera, O. del Hierro, M. Pinto, and J. M. Gutiérrez. 2015. A framework for species distribution modeling with improved pseudo-absence generation. Ecological Modelling 312:166-174. https://doi.org/10.1016/j.ecolmodel.2015.05.018

Johnson, D. H. 1980. The comparison of usage and availability measurements for evaluating resource preference. Ecology 61:65-71. https://doi.org/10.2307/1937156

Johnson, C. J., S. E. Nielsen, E. H. Merrill, T. L. McDonald, and M. S. Boyce. 2006. Resource selection functions based on use- 
availability data: theoretical motivation and evaluation methods. Journal of Wildlife Management 70:347-357. https://doi. org/10.2193/0022-541X(2006)70[347:RSFBOU]2.0.CO;2

Jones, J. 2001. Habitat selection studies in avian ecology: A critical review. The Auk 118:557-562. https://doi.org/10.1093/auk/118.2.557

Jug, D., M. Brmez, M. Ivezic, B. Stipesevic, and M. Stosic. 2008. Effect of different tillage systems on populations of common voles (Microtus arvalis Pallas, 1778). Cereal Research Communications 36:923-926.

Kaufman, D. W., and G. A. Kaufman. 1990. Small mammals of wheat fields and fallow wheat fields in north-central Kansas. Transactions of the Kansas Academy of Science 93:28-37. https:// doi.org/10.2307/3628126

Keilwagen, J., I. Grosse, and J. Grau. 2014. Area under precisionrecall curves for weighted and unweighted data. PLOS ONE 9: e92209. https://doi.org/10.1371/journal.pone.0092209

Kremen, C., N. M. Williams, and R. W. Thorp. 2002. Crop pollination from native bees at risk from agricultural intensification. Proceedings of the National Academy of Science 99:16812-16816. https://doi.org/10.1073/pnas.262413599

Lewis, K. E., C. T. Rota, C. M. Lituma, and J. T. Anderson. 2019. Influence of the Agricultural Conservation Easement Program wetland practices on winter occupancy of Passerellidae sparrows and avian species richness. PLOS ONE 14:e0210878. https://doi. org/10.1371/journal.pone.0210878

Leyhe, J. E., and G. Ritchison. 2004. Perch sites and hunting behavior of Red-tailed Hawks (Buteo jamaicensis). Journal of Raptor Research 38:19-25.

Lobo, J. M., and M. F. Tognelli. 2011. Exploring the effects of quantity and location of pseudo-absences and sampling biases on the performance of distribution models with limited point occurrence data. Journal for Nature Conservation 19:1-7. https:// doi.org/10.1016/j.jnc.2010.03.002

Marion, W. R., and R. A. Ryder. 1975. Perch-site preferences of four diurnal raptors in northeastern Colorado. The Condor 77:350-352. https://doi.org/10.2307/1366241

Marshall, E. J. P., T. M. West, and D. Kleijn. 2006. Impacts of an agri-environment field margin prescription on the flora and fauna of arable farmland in different landscapes. Agriculture, Ecosystems, and Environment 113:36-44. https://doi.org/10.1016/ j.agee.2005.08.036

Manly, B. F. J., L. L. McDonald, D. L. Thomas, T. L. McDonald, and W. P. Erickson. 2002. Resource selection by animals. Second. Kluwer Academic Publishers, Boston, MA. https://doi. org/10.1007/978-94-011-1558-2

Millsap, B. A., and M. N. LeFranc. 1988. Road transect counts for raptors: how reliable are they? Journal of Raptor Research 22:8-16.

Morefield, P. E., S. D. LeDuc, C. M. Clark, and R. Iovanna. 2016. Grasslands, wetlands, and agriculture: the fate of land expiring from the Conservation Reserve Program in the Midwestern United States. Environmental Research Letters 11. https://doi. org/10.1088/1748-9326/11/9/094005
Muff, S., J. Signer, and J. Fieberg. 2020. Accounting for individualspecific variation in habitat-selection studies: Efficient estimation of mixed-effects models using Bayesian or frequentist computation. Journal of Animal Ecology 89:1-13. https://doi. org/10.1111/1365-2656.13087

Mushet, D. M., J. L. Neau, and N. H. Euliss Jr. 2014. Modeling effects of conservation grassland losses on amphibian habitat. Biological Conservation 174:93-100. https://doi.org/10.1016/j. biocon.2014.04.001

Nad'o, L., and P. Kaňuch. 2018. Why sampling ratio matters: Logistic regression and studies of habitat use. PLOS ONE 13: e0200742. https://doi.org/10.1371/journal.pone.0200742

Otto, C. R. V., H. Zheng, A. L. Gallant, R. Iovanna, B. L. Carlson, M. D. Smart, and S. Hyberg. 2018. Past role and future outlook of the Conservation Reserve Program for supporting honey bees in the Great Plains. Proceedings of the National Academy of Science 115:7629-7634. https://doi.org/10.1073/pnas.1800057115

Paz, A., D. Jareño, L. Arroyo, J. Viñuela, B. Arroyo, F. Mougeot, J. J. Luque-Larena, and J. A. Fargallo. 2012. Avian predators as a biological control system of common vole (Microtus arvalis) populations in north-western Spain: experimental set-up and preliminary results. Pest Management Science 69:444-450. https:// doi.org/10.1002/ps.3289

Pearlstine, E. V., F. J. Mazzotti, and M. H. Kelly. 2006. Relative distribution and abundance of wintering raptors in agricultural and wetland landscapes of south Florida. Journal of Raptor Research 40:81-85. https://doi.org/10.3356/0892-1016(2006)40 [81:RDAAOW]2.0.CO;2

Petersen, L. 1979. Ecology of great horned owls and red-tailed hawks in southeastern Wisconsin. Technical Bulletin, Department of Natural Resources, Madison, Wisconsin, USA.

Phillips, S. J., M. Dudik, J. Elith, C. H. Graham, A. Lehmann, J. Leathwick, and S. Ferrier. 2009. Sample selection bias and presence-only distribution models: implications for background and pseudo-absence data. Ecological Applications 19:181-197. https://doi.org/10.1890/07-2153.1

Preston, C. R. 1990. Distribution of raptor foraging in relation to prey biomass and habitat structure. The Condor 92:107-112. https://doi.org/10.2307/1368388

Preston, C. R., and R. D. Beane. 1996. Occurrence and distribution of diurnal raptors in relation to human activity and other factors at Rocky Mountain Arsenal, Colorado. Pages 365-374 in D. M. Bird, D. E. Varland, and J. J. Negro, editors. Raptors in human landscapes: adaptations to built and cultivated environments. Academic Press, London., UK. https://doi. org/10.1016/B978-012100130-8/50036-5

Preston, C. R., and R. D. Beane. 2009. Red-tailed Hawk (Buteo jamaicensis). In A.F. Poole, editor. Birds of North America Online. Cornell Lab of Ornithology, Ithaca, NY, USA.

Prieur, A-G. A., and R. K. Swihart. 2020a. Field attributes and farming practices associated with vole (Microtus) damage in cover-cropped fields. Agriculture, Ecosystems, and Environment, in press. https://doi.org/https://doi.org/10.1016/j.agee.2020.106950 
Prieur, A-G. A., and R. K. Swihart. 2020b. Palatability of common cover crops to voles (Microtus). Crop Protection 133. https://doi.org/https://doi.org/10.1016/j.cropro.2020.105141

Prieur, A-G. A., and R. K. Swihart. 2020c. Vole activity surveys predict damage to cover-cropped soybean plants. Annals of Applied Biology. https://doi.org/https://doi.org/10.1111/aab.12650

R Core Team. 2019. R: A language and environment for statistical computing. R Foundation for Statistical Computing, Vienna, Austria. https://www.R-project.org/.

Riffell, S. D., D. Scognamillo, and L. W. Burger. 2008. Effects of the Conservation Reserve Program on Northern Bobwhite and grassland birds. Environmental Monitoring and Assessment 146:309-323. https://doi.org/10.1007/s10661-007-0082-8

Rollins, D., and E. K. Lyons. 2009. Assessing Bobwhite responses to the Environmental Quality Incentives Program implementation in the Rolling Plains of Texas. Pages 45-60 in L. W. Jr. Burger and K. O. Evans, editors. Managing working lands for Northern Bobwhite: The USDA NRCS Bobwhite Restoration Project. Natural Resources Conservation Service, Washington D.C., USA. [online] URL: https://www.landcan.org/pdfs/final_report. pdf.

Šálek, M., J. Kreisinger, F. Sedláček, and T. Albrecht. 2010. Do prey densities determine preferences of mammalian predators for habitat edges in an agricultural landscape? Landscape and Urban Planning 98:86-91. https://doi.org/https://doi.org/10.1016/j. landurbplan.2010.07.013

Samson, F., and F. Knopf. 1994. Prairie conservation in North America. BioScience 44:418-421. https://doi.org/10.2307/1312365

Schnell, G. D. 1968. Differential habitat utilization by wintering rough-legged and red-tailed hawks. The Condor 70:373-377. https://doi.org/10.2307/1365932

Shave, M. E., and C. A. Lindell. 2017. Occupancy modeling reveals territory-level effects of nest boxes on the presence, colonization, and persistence of a declining raptor in a fruitgrowing region. PLOS ONE 12:e0185701. https://doi. org/10.1371/journal.pone.0185701

Shave, M. E., B. Lundrigan, and C. Lindell. 2018a. Effects of American kestrel nest boxes on small mammal prey in cherry orchards. Pages 224-230 in D.M. Woods, editor. Proceedings of the 28th Vertebrate Pest Conference. University of California Davis, Davis, California.

Shave, M. E., S. A. Shiff, J. L. Elser, and C. A. Lindell. $2018 b$. Falcons using orchard nest boxes reduce fruit-eating bird abundances and provide economic benefits for a fruit-growing region. Journal of Applied Ecology 55:2451-2460. https://doi.org/ https://doi.org/10.1111/1365-2664.13172

Shoemaker, K. T., L. J. Heffelfinger, N. J. Jackson, M. E. Blum, T. Wasley, and K. M. Stewart. 2018. A machine-learning approach for extending classical wildlife resource selection analyses. Ecology and Evolution 8:3556-3569. https://doi.org/10.1002/ ece 3.3936

Shupe, S., and R. Collins. 1983. A winter roadside survey of hawks in eastern Nemaha County, Nebraska. Nebraska Bird Review $51: 19-22$.
Smallwood, J. A., M. F. Causey, D. H. Mossop, J. R. Klucsarits, R. J. Robertson, S. Robertson, J. Mason, M. J. Maurer, R. J. Melvin, R. D. Dawson, G. R. Bortolotti, J. W. Jr. Parrish, T. F. Breen, and K. Boyd. 2009. Why are American kestrel (Falco sparverius) populations declining in North America? Evidence from nest-box programs. Journal of Raptor Research 43:274-282. https://doi.org/10.3356/JRR-08-83.1

Smallwood, J. A., and D. M. Bird. 2002. American Kestrel (Falco sparverius). In A.F. Poole, editor. Birds of North America Online. Cornell Lab of Ornithology, Ithaca, NY, USA.

Sofaer, H. R., J. A. Hoeting, and C. S. Jarnevich. 2019. The area under the precision-recall curve as a performance metric for rare binary events. Methods in Ecology and Evolution 10:565-577. https://doi.org/10.1111/2041-210X.13140

Stanton, R. L., C. A. Morrissey, and R. G. Clark. 2018. Analysis of trends and agricultural drivers of farmland bird declines in North America: A review. Agriculture, Ecosystems, and Environment 254:244-254. https://doi.org/10.1016/j.agee.2017.11.028

Stewart, B. P., T. A. Nelson, K. Laberee, S. E. Nielsen, M. A. Wulder, and G. Stenhouse. 2013. Quantifying grizzly bear selection of natural and anthropogenic edges. The Journal of Wildlife Management 77:957-964. https://doi.org/10.1002/ jwmg. 535

Thomas, D. L., and E. J. Taylor. 2006. Study designs and tests for comparing resource use and availability II. The Journal of Wildlife Management 70:324-336. https://doi.org/10.2193/0022-541X (2006)70[324:SDATFC]2.0.CO;2

Toland, B. R., and W. H. Elder. 1987. Influence of nest-box placement and density on abundance and productivity of American Kestrels in central Missouri. The Wilson Bulletin 99:712-717.

USDA National Agricultural Statistics Service (NASS). $2019 a$. U.S. Census of Agriculture: United States summary and state data. US Department of Agriculture, Washington D.C., USA.

USDA National Agricultural Statistics Service Cropland Data Layer (NASS). 2019 b. USDA-NASS, Washington, D.C. Available at https://nassgeodata.gmu.edu/CropScape/. Accessed August 10, 2020.

Valdez, U., S. Robertson, B. Robertson, and K. L. Bildstein. 2000. Nestbox use by American Kestrels (Falco sparverius) and European Starlings (Sturnus vulgaris) in eastern Pennsylvania. Pennsylvania Birds 14:150-153.

Villamil, M. B., G.A. Bollero, R.G. Darmody, F.W. Simmons, and D.G. Bullock. 2006. No-till corn/soybean systems including winter cover crops: Effects on soil properties. Soil Science Society of America Journal 70:1936-1944. https://doi.org/10.2136/ sssaj2005.0350

Viñuela, J. 1997. Road transects as a large-scale census method for raptors: the case of the Red Kite Milbus milvus in Spain. Bird Study 44:155-165. https://doi.org/10.1080/00063659709461051

Warton, D. I., and L. C. Shepherd. 2010. Poisson point process models solve the "pseudo-absence problem" for presence-only data in ecology. The Annals of Applied Statistics 4:1383-1402. https://doi.org/10.1214/10-AOAS331 
Wilcoxen, C. A., J. W. Walk, and M. P. Ward. 2018. Use of cover crop fields by migratory and resident birds. Agriculture, Ecosystems, and Environment 252:42-50. https://doi.org/10.1016/ j.agee.2017.09.039

Wilson, A., M. Brittingham, and G. Grove. 2010. Association of wintering raptors with Conservation Reserve Enhancement Program grasslands in Pennsylvania. Journal of Field Ornithology 81:361-372. https://doi.org/10.1111/j.1557-9263.2010.00292.x

Worm, A. J., M. M. Bobowski, and T. S. Risch. 2013. Perch-type characteristics of overwintering Red-tailed Hawks (Buteo jamaicensis) and American Kestrels (Falco sparverius). Journal of the Arkansas Academy of Science 67:159-162.

Yan, L., and D. P. Roy. 2016. Conterminous United States crop field size quantification from multi-temporal Landsat data. Remote Sensing of Environment 172:67-86. https://doi. org/10.1016/j.rse.2015.10.034

Zagorski, M. E. 2019. Winter ecology of raptors in cover-cropped agroecosystems in western Indiana. Master's, Purdue University, West Lafayette, Indiana, USA.

Zagorski, M. E., and R. K. Swihart. 2020. Killing time in cover crops? Artificial perches promote field use by raptors. Annals of Applied Biology. https://doi.org/https://doi.org/10.1111/aab.12623

Editor-in-Chief: Keith A.Hobson Subject Editor: Andrew J.Campomizzi
Sponsored by the Society of Canadian Ornithologists and Birds Canada

Parrainée par la Société des ornithologistes du Canada et Oiseaux Canada

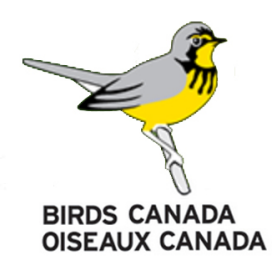

